8. Konah S.S. (2015) Teoretichni pidhodi do viznachennya sutnosti ponyattya «sfera poslug. [Theoretical approach to the understanding of the daily conditions «sphere of services»]. Naukovij visnik Mizhnarodnogo gumanitarnogo universitetu. Seriya: Ekonomika i menedzhment. Vol. 12. (pp. 46-49). [in Ukrainian].

9. Marchenko T.G. (2012) Pokazniki ta metodi ocinki yakosti sistemi nadannya poslug call-centriv. [Indicators of that method of evaluating the accuracy of the system of services of the call-center]. Teoriya ta praktika derzhavnogo upravlinnya. Vol. 3 (38). (pp. 178-185). [in Ukrainian].

10. Harrington Dzh. (1990) Upravlenie kachestvom v amerikanskih korporaciyah. [Quality Management in American Corporations]. Moscow. 11. Fleming Dzh.. Asplend Dzh. Upravlenie kachestvom uslug: metod Human Sigma. [Service Quality Management: Human Sigma Method]. Moscow.

12. Yak pidvishiti efektivnist roboti call-centriv i utrimati kliyentiv. [How to increase call center efficiency and retain customers] Retrieved from: https://rau.ua/uk/dosvid/effective-call-center-retail.

UDC 338.436(477):330.322.1

Nehoda Yu., Ph.D., Associate Professor of the Department of Finance

National University of Life and Environmental Sciences of Ukraine

\title{
THE SPECIFICS AND ASPECTS OF DEVELOPMENT OF MIXED AGRARIAN ECONOMY
}

The article specifics of agrarian entrepreneurship were determined. There were stages identified that had taken place during transformation process of social-economic structure of business forms and forming of farming structure during agrarian and land reforms implementation. It was emphasized that formation and exact development of enterprises of entrepreneurial type are positive result of agrarian reform, and are also an important prerequisite of further development of market relations in the agrarian sector. There were variants of models of citizens' household conversion detached. It was indicated that agrarian economy transformation can't get singlevalue estimate. There were determined the main middle term tendencies of structural changes in the agrarian sector of economy.

Key words: agrarian sector, mixed economy, population household, economy, transformation, farming enterprises.

Негода Ю.В.

\section{ОСОБЛИВОСТІ ТА НАПРЯМИ РОЗВИТКУ БАГАТОУКЛАДНОЇ АГРАРНОЇ ЕКОНОМІКИ}

В статті визначено особливості аграрного підприємництва. Виділено етапи які відбулися в процесі трансформації соціально-економічної структури форм господарювання й формуванні фермерського укладу при проведенні аграрної і земельної реформ. Наголошено, що формування і певний розвиток господарств підприємницького типу є позитивним наслідком аграрної реформи, важливою передумовою подальшого розвитку ринкових відносин в аграрному секторі. Виділено варіанти моделей перетворення господарств населення. Зазначено, що трансформація аграрної економіки не може отримати однозначної оцінки. Виявлено основні середньострокові тенденції структурних змін в аграрному секторі економіки.

Ключові слова: аграрний сектор, багатоукладність, господарства населення, економіка, трансформація, фермерські господарства

Негода Ю.В.

\section{ОСОБЕННОСТИ И НАПРАВЛЕНИЯ РАЗВИТИЯ МНОГОУКЛАДНОЙ АГРАРНОЙ ЭКОНОМИКИ}

В статье определены особенности аграрного предпринимательства. Выделены этапы, которые произошли в процессе трансформации социально-экономической структуры форм хозяйствования и формировании фермерского уклада при проведении аграрной и земельной реформ. Отмечено, что формирование и определенное развитие хозяйств предпринимательского типа является положительным следствием аграрной реформы, важной предпосылкой дальнейшего развития рыночных отношений в аграрном секторе. Выделены варианты моделей преобразования хозяйств населения. Отмечено, что трансформация аграрной экономики не может получить однозначной оценки. Выявлены основные среднесрочные тенденции структурных изменений в аграрном секторе экономики.

Ключевые слова: аграрный сектор, многоукладность, хозяйства населения, экономика, трансформация, фермерские хозяйства. 
Articulation of the problem. Fundamental transformations concerning further development of enterprising subjects of agrarian production in terms of regulated market economy and socially directed reforms got acutely relevant economic problem, that dictates the necessity for scientific economic argumentation of different forms of enterprising development in the agrarian sector. That's why macroeconomic problems of establishing and development of forms of enterprising in the agrarian economy received comprehensive coverage.

The analysis of the latest researches where the solving of the problem was started. The significant contribution into researches of the theoretical bases and practical questions concerning the ways of mixed agrarian economy development was done by the list of local scientists-economists, such as: Vesilieva L.M., Gudzynskyi S.O., Kurylo S.M., Lypchuk V.V., Lozynska I.V., Pavlenko A.O., Prokopa I.V., Shepotko L.O., Yarovyi V.D., etc. Different aspects of this questions were examined in the scientific researches of these authors but they require further more detailed research of determination of mixed agrarian economy ways of development.

The aims of the article. The main aim is to determine the specific features and the ways of development of mixed agrarian economy.

Composition of main material of the research with complete argumentation of received scientific results. We shall the specific features of agrarian enterprising:

$\checkmark$ for the reasons of close connection of economic and biological factors in the agrarian production, any entrepreneur is applied besides managing, resources and innovative requirements but also he should know elementary bases of agricultural production and have practical skills of its carrying on;

$\checkmark$ any agrarian enterprise development dependence on land market formation problem solution;

$\checkmark$ respectively high demand in credit resources because of seasonality of agricultural production and long-term production process in its separate fields;

$\checkmark$ risk, that is peculiar for all types of enterprises, especially it becomes strongly obvious in agricultural enterprise because of its dependence on agricultural production from naturalclimatic conditions, which preconditions the necessity to its sufficient insurance and state support. The higher risk of agricultural production requires the simultaneous participation of agrarian enterprises in n non-agricultural types of business not only in rural areas but also in nearby urban settlements;

$\checkmark$ agricultural production is always multifunctional and is conducted in variety of soil and climatic conditions that's why agrarian enterprise must be done in completely different managing-legal forms that should be adequate and corresponding to concrete terms of production of agricultural products.

Thus, we have separated several stages in transformation of social economic structure of farming forms and formation of household during agricultural and land reforms implementation in our country. They are as following: the first stage (1990-1993yy) was characterized by rapid formation of rural (farming) enterprises within favorable conditions for this process, such as: the availability of a substantial fund of land redistribution, its free of charge allocation, lending at a preferential interest and a significant number of those wishing to start an independent activity. Farming enterprises functioning is not only agricultural products manufacturing, their meaning and place in farmer's life have more significant meaning. Taking into account above mentioned, the saying of Miroshnychenko M. is worth of interest and it is about that farming enterprises "in our terms show not only new form of production organizing, but also new type of production relations, new connections between themselves within framework of agricultural sector and the agricultural sector with industry. This explains the complexity of solving problems of formation and development of farms, improving their competitiveness and efficiency compared to other forms of organization of agricultural production" [4]. At this stage, increased attention was paid to the farms by the government, which hoped in the short term to achieve their significant development as major producers of agricultural products. 
"Farming enterprises started growing rapidly on the beginning of 90ies of the last century, if in 1990 year there were 82 such enterprises registered that in their usage had 2 thousand Ha of agricultural lands, then five years after their number grew till 34,8 thousand and agricultural lands in their usage increased up to 786,4 thousands Ha, during the whole period of farming development in Ukraine their biggest number was recorded in 2007 year [3]. Such fluctuations in farming enterprises growth can be explained that during the first years of the agrarian reform implementation those wishing to become farmers had a possibility to get in their household up to $50 \mathrm{Ha}$ of agricultural lands and up to $100 \mathrm{Ha}$ of total land area. Due to their property shares, they were able to obtain machinery and other means of production. And in those circumstances, the prices for machinery and fertilizers were more or less affordable for farmers. There was also a possibility to purchase previously used equipment from collective farming enterprises at relatively low prices. The deepening of price disparity and severe crisis in all the economy including agriculture, hyperinflation all this affected on that those wishing to become farmers did not have possibility for that and, first of all, "start-up capital" for that, and without this it was impossible to establish own enterprise.

According to the results of 2017 year the number of registered farming enterprises in Ukraine amounted 34,1 thousand that is one fifth less than one year earlier. At the same time, as of the $1^{\text {st }}$ of November 2017 year, the biggest amount of farming enterprises was registered in Odeska (4,0 thousand), Mykolayvska (3,4 thousand) regions. The smallest amount of faming enterprises can be found in Rivnenska - $373(1,1 \%)$, Ivano-Frankivska - $516(1,5 \%)$ and Chernivetska $-587(1,7 \%)$ regions, in total amount the number of farming enterprises accounts 1476 in these regions, and their share in the total amount of farming enterprises is the smallest $-4,3 \%$. Thus, in steppe area, there are more farming enterprises functioning where there are more favorable conditions that allow to grow crops and sunflowers that have the highest profitability rate.

The differentiating features of the second stage (1994-1999yy) were:

$\checkmark$ significant decrease in farming land redistribution fund;

$\checkmark$ transfer to providing newly established households land shares according to the average district norms that reduced their average land area in comparison with previously established enterprises;

$\checkmark$ cancellation of preferential lending;

$\checkmark$ escalation of economic difficulties in farmering development because of price disparity, land ownership availability for a price, etc.

The third stage of farming enterprises development (2000-2009 yу.) can be characterized by stabilization of their amount and increase of significance of farming style in the mixed economy system. In 2000-2005yy there was stable tendency of agricultural products production increase reached, its volume grew in 2,6 times. At the same time the farming enterprises were embodying both entire production functions and also significantly were helping in solving social problems of village: they provided rural population employment, first of all, of young people, rural inhabitants' income increase, maintained the rural way of life, ensured rural territories development.

According to the data of the State Statistics of Ukraine the growth rates of produced by farmers during 2000-2005 years agricultural products were far ahead of agricultural enterprises and citizens households. This tendency was especially obvious on the background of inertial production growth in the agricultural enterprises where the products volume in price value for the same period of time increased in 1,2 times but in faming enterprises this volume grew in 2,6 times, and in citizens households it increased in only 1,1 times.

The fourth stage of farming progression has been defined since 2006 year, when the process of farming enterprises consolidation became more rapid due to concentration growth, production unifying, merge of small farms by larger ones. During this period, the number of farming enterprises shortened but their areas enlarged. Only for 2006-2017yy in Ukraine 8310 farming enterprises ceased to exist. Thus, the volume of farming land increased more than twice, in particular, arable land increased in 2,1 times, and per one farming enterprise their 
volume increased in average in 2,4 and 2,5 times and in 2017 accounted accordingly 134,1 and 130,5 Ha, and this corresponds to general tendencies in Ukraine till land use consolidation.

Social-economic differentiation was done in the framework of deep differentiation of arable land size and work results. Enterprises concentrating according to their farm land volume shows that farming sector mainly includes 10602 enterprises with total volume from 21 till $50 \mathrm{Ha}(31,00 \%)$ and +1749 enterprises from 50 till $500 \mathrm{Ha}(26,7 \%)$.

Generally, formation and certain development of enterprises of entrepreneur type are a positive result of the agricultural reform, and an important prerequisite of further market relations development in the agrarian sector. In Ukraine there was business form restored that is inherent to all economically developed countries. It is exactly in the farming enterprises structures that the highest possible motivation of productive and creative work is achieved.

In the groundbreaking changes of the agricultural relations there is fundamentally new assessment of place, role and citizens household development prospects required. They must be considered economically independent and equal to the other forms of economic management in the agricultural economy. And these small owners' activities should be considered socially required productive work. Citizens' households are specific subject of the agrarian market that is based on recourses use and labor potential of rural families, who have been dealing with specific production form since the beginning of 20-ies XX century during establishing collective farms sector with state-owned legal entity on means of production, including land.

In terms of the agricultural relations transformation, endurance of business activities new forms establishing in the agrarian sector, the role of citizens households, as the most flexible and pretty stable, and self-managing organizational form, has increased.

As Shepotko L.O., Prokopa I.V., Gudzynskyi S.O., Yarovyi V.D. specify "in independent Ukraine the process of agricultural production transformation from administrative command functioning system to new market terms underwent pretty painfully. The system of management in rural areas that had formed for 1998 was really ineffective, despite that the state invested 4,7 billion UAH of assignations into material and technical recourses, $93 \%$ of enterprises stayed unprofitable, at the same time the private sector without any state support, brought 30 billion UAH of profits [5]. During 90-ies gross agricultural product in Ukraine decreased more than $50 \%$ (Table 1).

Table 1.

Gross agricultural product of Ukraine

In stable prices 2010, bln., UAH

\begin{tabular}{|l|c|c|c|c|}
\hline \multicolumn{1}{|c|}{ Indicator } & $2010 \mathrm{y}$. & $2015 \mathrm{y}$ & $2016 \mathrm{y}$ & $2017 \mathrm{y}$. \\
\hline \multicolumn{5}{|c|}{ All types of enterprises } \\
\hline Gross product - total including: & 194886,5 & 239467,3 & 254640,5 & 249157,0 \\
\hline Crop production & 124554,1 & 18439,0 & 185052,1 & 179474,6 \\
\hline Animal products & 70332,4 & 71028,3 & 69588,4 & 69682,4 \\
\hline \multicolumn{5}{|c|}{ Agricultural enterprises } \\
\hline Gross product - total including: & 94089,0 & 131918,6 & 145119,0 & 140535,2 \\
\hline Crop production & 66812,7 & 99584,7 & 113392,6 & 108601,1 \\
\hline Animal products & 27276,3 & 32333,9 & 31726,4 & 31934,1 \\
\hline \multicolumn{5}{|c|}{ Including farming enterprises } \\
\hline Gross product - total including: & 11965,8 & 18909,3 & 22101,4 & 21743,1 \\
\hline Crop production & 10840,9 & 17565,4 & 20705,3 & 20338,8 \\
\hline Animal products & 1124,9 & 1343,9 & 1396,1 & 1404,3 \\
\hline \multicolumn{5}{|c|}{ Citizens households } \\
\hline Gross product - total including: & 100797,5 & 107548,7 & 109521,5 & 108621,8 \\
\hline Crop production & 57741,4 & 68854,3 & 71659,5 & 70873,5 \\
\hline Animal products & 43056,1 & 38694,4 & 37862,0 & 37748,3 \\
\hline
\end{tabular}

The rate of citizens' households in the total volume of the agricultural production in 1990 year made $30,6 \%$ at the same time the agricultural enterprises accounted $70 \%$. The agricultural 
production visible decrease was noticed from the beginning of 1991 year. The citizens' households and other forms of subsidiary agricultural production took the vast majority in the structure of food balance, because farmers and other forms of agricultural business organizationally and economically did not become stronger for that time and did not get the required development.

During 2010 - 2017 years the tendency stayed unchanged where citizens' households took significant place in the structure of agricultural products production. Therefore, in 2017 year in the structure of gross agricultural product the citizens households occupied 43,6\%, agricultural enterprises took $56,4 \%$ including farming enterprises $-15,47 \%$.

During the process of the agricultural formation between different categories of enterprises there was clear sector work division formed, that was defined by technical technological level, production concentration, labor intensity, specifics of labor and material recourses use. Vasilieva L.M. notifies that "new relations of ownership caused transfer $t$ real change of productive relations and interests of agrarian goods producers in the agrarian sector, and exactly productive relations formation on the basis of the private ownership more fully corresponds to the nature of goods money relationship and interests of agrarian goods producers, and the important place among various forms of enterprises is occupied by personal citizens households" [1].

In 1990 the agricultural enterprises produced absolute number of vegetables $(70,7 \%)$, meat $(76,5 \%)$, milk $(83,4 \%)$. Steady they were losing their leading position on production all types of products. Thus, in 2017 agricultural enterprises in proportion of main types of products manufacture occupied the following positions: for the vegetables production $-14,5 \%$, meat $64 \%$, milk $-26,9 \%$. In current conditions citizens households produced absolute number of potatoes $-98,1 \%$, vegetables $-85,5 \%$, milk $-73,1 \%$. Starting from 1998 year, the production of milk and meat in terms of its rapid decrease in agricultural enterprises, has been increasingly concentrated in the citizens households. They are noticed to have higher productivity, at the same time in agricultural enterprises it catastrophically declines. We can say the only thing that there is a risk in population providing with meat and milk products of own production.

Under such conditions, the agrarian households provide for at least a quantitative solution to the food problem. Meanwhile, it is likely that nobody will deny the thesis according to it in distant prospect, at the whole the sector of agrarian households should lose their current social economic meaning. Its existence is a sign of pre-industrial era of the agrarian production that is anachronism for industrial, and especially post-industrial development. Nowadays there are no such countries left in the developed western countries. There are an absolute majority of small and middle-sized enterprises but these are commercial (business) farms.

Maximum level of development of citizens' households in our country was reached in 2014 year, when the rate of their production made $44,7 \%$ in the structure of gross agricultural products. Then there was insignificant production slowdown till 43,6\% seen in 2017 year.

We should specify that production growth of citizens households can't be evaluated clearly and it indicates a high level of incompleteness of market reforms in the agrarian sphere. This event can be distinguished from one side as an indicator of progressive changes in the agrarian structure of the country, and as a proof of advantages of private family agricultural production in comparison with collective one. From the other side, in the development of private citizens households there is a crisis of agriculture seen, in terms of which the economic activity of peasants is forced that comes out of survival logic, but not from the growth of effectiveness to transfer from collective sector to private. The cross section enlargement of citizens' private households in the agrarian structure can be considered as a negative result conditioned not by economic activity of private households but by production decrease in the agricultural enterprises.

Some national authors recognized positive things in such structural changes, especially at the beginning of reform implementation. They claimed that citizens' households including private household plots, in comparison with huge ones were more flexible that's why they were more adapted to the market terms. [2]. 
From our point of view, citizens' households can be prioritized form of management because of their size and level of technical equipment they are not able to assimilate scientific technical progress achievements and are based on peasants' exploitation. We are deeply convinced that one of the most important directions of structural rebuilding of agrarian sector of economy should be refocusing to big enterprises rate increase in agricultural products production.

An important role in citizens households work improvement can have the following variants of reformation forms:

$\checkmark$ steady reformation of citizens households into enterprises of farming type;

$\checkmark$ citizens' households attraction to integrated formation activities, establishing in cooperatives and agricultural firms self-supporting units for purchase, processing and sell of products;

$\checkmark$ rural residents' independent cooperation.

At the same time sociological researches show that most of the peasants don't take seriously the idea of farming because of unwillingness to take responsibility for risks and their habit to collective forms of agricultural production. As the only serious motivating factor for farming enterprise establishing can be considered land ownership realization and work for themselves. For this scheme to be implemented it is necessary to establish tens of thousands of small business leaders who could have played a role of changes guide in villages.

Nowadays the small agricultural enterprises grow very slow and fragmentarily, prone to influence from massive market failures, high transactional expenses and risks, and also services shortcomings. Market imperfection and gaps in the institutional structure convert into loses for the account of lost growth opportunities, and also small business employees' welfare decrease. All of this require effective methods working out and ways to improve the institutional reformation of the agrarian sector of economy.

We should point out that big enterprises and households execute system-creating role, there are approximately $75 \%$ of main sources of agriculture concentrated. During agricultural reform the significant differentiation of big enterprises economical state levels took place, most of them had their production potential destroyed. If in 1990 year the share of unprofitable agricultural enterprises in Ukraine accounted only $0,4 \%$, then there were more than $46 \%$ of unprofitable enterprises makes $13,3 \%$ (Table 2).

Table 2.

Main indicators of agricultural enterprises activities

\begin{tabular}{|c|c|c|c|c|c|c|c|c|}
\hline \multirow[t]{2}{*}{ Indicator } & \multirow[t]{2}{*}{$2005 y}$. & \multirow[t]{2}{*}{$2010 \mathrm{y}}$. & \multirow[t]{2}{*}{$2014 \mathrm{y}}$. & \multirow[t]{2}{*}{$2015 \mathrm{y}}$. & \multirow[t]{2}{*}{$2016 \mathrm{y}}$. & \multirow[t]{2}{*}{$2017 \mathrm{y}}$. & \multicolumn{2}{|c|}{$2017 y$. in \% till } \\
\hline & & & & & & & $2005 y$. & $\begin{array}{c}2016 \\
\text { y. }\end{array}$ \\
\hline $\begin{array}{l}\text { Financial result } \\
\text { till taxation, bln, } \\
\text { UAH }\end{array}$ & 3489,7 & 17320,5 & 21495,9 & 101996,1 & 90122,1 & 78786,1 & 22 g.p. & 87,4 \\
\hline $\begin{array}{l}\text { Net profit (loss) } \\
\text { bln., UAH }\end{array}$ & 3464,6 & 17253,6 & 21413,4 & 101912,2 & 89816,3 & 78457,7 & 22 g.p. & 87,3 \\
\hline $\begin{array}{l}\text { Enterprises that } \\
\text { got net profit in } \\
\text { percentage to total } \\
\text { amount }\end{array}$ & 64,7 & 69,6 & 84,7 & 88,9 & 88,4 & 86,7 & $\begin{array}{l}22,0 \\
\text { g.p. }\end{array}$ & $\begin{array}{l}-1,7 \\
\text { g.p. }\end{array}$ \\
\hline $\begin{array}{l}\text { Enterprises that } \\
\text { got net loss in } \\
\text { percentage to total } \\
\text { amount }\end{array}$ & 35,3 & 30,4 & 15,3 & 11,1 & 11,6 & 13,3 & $\begin{array}{l}-22,0 \\
\text { g.p. }\end{array}$ & $\begin{array}{l}1,7 \\
\text { g.p. }\end{array}$ \\
\hline $\begin{array}{l}\text { Profitability level } \\
\text { of all activities, } \%\end{array}$ & 9,8 & 17,5 & 9,3 & 30,4 & 25,6 & 18,7 & 8,9 g.p. & $\begin{array}{l}-6,9 \\
\text { g.p. }\end{array}$ \\
\hline $\begin{array}{l}\text { Profitability level } \\
\text { of operative } \\
\text { activities, \% }\end{array}$ & - & 24,5 & 21,4 & 43,0 & 33,6 & 23,5 & -1 & $\begin{array}{l}-10,1 \\
\text { g.p. }\end{array}$ \\
\hline
\end{tabular}

We should note that the transformation of the agrarian economy can't be given clear assessment. As the result of enterprises privatization and land ownership transformation in the 
agricultural sector there was new system of organizational legal management forms established where farming enterprises sector functions, land use of rural population has been enlarged (owners of private households, farms and gardens, etc.). Rural style of life restoring became, of course, a positive process. The expansion of management forms range was also positive because of emergence in the agricultural sector structure together with farming enterprises, new types of cooperation, farming enterprises associations, etc. However, we think that further development of the agricultural economy must be connected with large-scale production renewal, first of all, agricultural production cooperatives mostly of vertical type, agricultural firms, agrarian industrial complexes, agricultural holdings in case of their size optimization and their activities fulfilling on the basis of the market methods and principals of internal selfsufficiency. Ultimately, the overall tendency of transferring to small-scale farm in the village must be overcome.

Conclusion. Thuswise, the fulfilled research allowed to find out the main middle terms tendencies of structural changes in the agrarian economy sector:

- steady process of farming enterprises enlargement on account of concentration growth, enterprises amalgamation and procedure of big enterprises merge of small-scale enterprises;

- production specialization extension;

- fundamental growth of cooperative and integrational processes;

- citizens households cross section decrease in gross product production on account of agricultural enterprises and farming enterprises growth;

- strengthening of state support of small-scale enterprises.

\section{Список бібліографічного опису:}

1.Васільєва Л.М. Стан і розвиток особистих господарств населення Дніпропетровської області. Вісник ДДАУ. 2008. № 1. C. $118-122$.

2.Липчук В.В. Курило С.М. Перспективи розвитку особистих господарств населення. Економіка АПК. 2001. №3. С. $106-109$.

3.Лозинська І.В., Павленко А.О. Сучасний стан та особливості розвитку фермерських господарств. Вісник Сумського національного аграрного університету. 2017. Вип. 4. С. 77-80.

4.Мірошниченко М. Фермерство: проблеми становлення, розвитку та ефективність. Економіка Украӥни. 1995. №2. С. 69-73.

5. Шепотько Л.О., Прокопа І.В., Гудзинський С.О., Яровий В.Д. Сільський сектор України на рубежі тисячоліть. У 2-х т.: Т.1. Потенціал сільського сектору. К.: Ін-т економіки НАН України, 2003. 466 с.

\section{References:}

1.Vasileva, L.M. (2008), Stan i rozvytok osobystykh hospodarstv naselennya Dnipropetrovs'koyi oblasti. [State and development of personal farms in Dnipropetrovsk region], Visnyk DDAU. no. 1, pp. 118-122.

2.Lipchuk, V.V. and Kurilo, S.M. (2001), Perspektyvy rozvytku osobystykh hospodarstv naselennya. [Prospects for personal farms development], Ekonomika APK. no. 3, pp. 106-109.

3.Lozynskaya, I.V. and Pavlenko, A.A. (2017), Suchasnyy stan ta osoblyvosti rozvytku fermers'kykh hospodarstv. [The current state and features of farm development], Visnyk Sums'koho natsional'noho ahrarnoho universytetu. no. 4, pp. 77-80.

4.Miroshnichenko, M. F. (1995), Fermerstvo: problemy stanovlennya, rozvytku ta efektyvnist'. [Farming: problems of formation, development and efficiency], Ekonomika Ukrayiny. no. 2, pp. 69-73.

5.Shepotko, L.O., Prokopa, I.V., Hudzinskiy, S.O. and Yaroviy, V.D. (2003), Sil's'kyy sektor Ukrayiny na rubezhi tysyacholit'. U 2-kh t.: T.1. Potentsial sil's'koho sektoru. [Rural sector of Ukraine at the turn of the millennium. In 2 volumes: Vol.1. Rural sector potential], Institute of Economics, NAS of Ukraine, Kiev, [Ukraine].

Рещензент д.е.н., професор Давиденко Н.М. 